\title{
Factors Influencing Individual Investor Behavior: An Empirical Study of City Karachi
}

\author{
Samreen Lodhi \\ Jinnah University for Women, Karachi, Pakistan
}

\begin{abstract}
This research study intends to examine the impact of financial literacy, accounting information, openness to experience and information asymmetry on individual investors' decision making through the empirical research of the people living in Karachi city. Any investment is made with the primary objective of earning return on the invested sum. And depending on the degree of risk any individual can be classified as either RISK TAKER or RISK AVERTER. Duration of an investment is another aspect for any investment decision. Short term investments are rather riskier than long term investments in securities.

Quantitative research was conducted to determine the relationship between desired explanatory and response variables. There were five independent variables including; financial literacy, high experience, use of accounting information, importance of analyzing financial statements and age that might affect the investment decision of any individual. Five different dependent variables were chosen from the questionnaire to reach to any conclusion they were; risk taking, preference investment in shares (risky investment), risk aversion, information asymmetry and shares investment.

The obtained results show that financial literacy and accounting information helps investors in lowering information asymmetry and allows investors to invest in risky instruments. But as age and experience increase investors preference changes to less risky investments, it does not mean that investor does not prefer to invest in shares, he will but with the intension of getting dividend return rather than capital gain.
\end{abstract}

\section{Introduction:}

Many researchers have discussed the investment behavior and tried to enhance the understanding of people managing investments in different ways. If we go through the available literature, it is mainly personal characteristics that influence investment decision making. The nature of psychological factors and individuals' behavior at the time of investment decision making is under discussion. Various psychological factors like beliefs, preferences, and psychological biases have been found.

The purpose of this study is to determine how the personal investment is affected by the level of knowledge an investor possesses about different investment instrument, knowledge of the relationship between risk and return along with the knowledge of companies performance analysis technique and portfolio management techniques.

The main reason for choosing Karachi for research is that; Karachi is the growth pole of Pakistan and is a residence of about one corer population and about 70 percent of investors. But since last four years there has been observed an apparent change in investors' preferences about investments, as law and order situation is critical to attract any foreign and local investment in Pakistan in general and Karachi in particular. Political and macroeconomical instability make investment environment less conducive for investors and continue depreciation of Pakistani currency has made investment in international trade less frequent. Electricity and fuel crises have made the industrial performance miserable that force the investors to move to neighboring country like Bangladesh.

\subsection{PROBLEM STATEMENT:}

To date however, there has been very little work on the impact of financial literacy, accounting information, openness to experience and information asymmetry in the individual investors' decision making. This research study intends to examine the impact of these factors on individual investors' decision making through the empirical research of the people living in Karachi city.

Any investment is made with the primary objective of earning return on the invested sum. And depending on the degree of risk any individual can be classified as either RISK TAKER or RISK AVERTER. Duration of an investment is another aspect for any investment decision. Short term investments are rather riskier than long term investments in securities. Real estate and stock market investments have been important subjects in the past years. More and more people invested in stocks and real estate. The reason for this was to secure money for future needs. But due to recent global financial crises, investment decisions are considered as important task in our daily life. For this reason, it is necessary to understand various factors which prompt 
individual investors to make individual investment decisions. The objective of this study is to identify some core factors which affect investors' willingness to invest.

\subsection{OBJECTIVES AND SCOPES OF THE RESEARCH:}

The objective of this study is:

- To determine the impact of financial literacy of individual investor on his investment decision.

- To examine the influence of accounting information of individual investor on his investment decision.

- How openness to experience affects the investment decision of individual investor?

- To study the effect of information asymmetry on decision making of individual investor.

\subsection{SIGNIFICANCE OF THE STUDY:}

As at now, there is very little work done about indicating the factors influencing the individual investors' behavior in Karachi in all sectors of economy. This study will provide information about the investment decision making of people belonging to different age group, different financial sectors, and their investment preferences.

Furthermore, it will help in determining whether the more experienced investor can only make good investment decision or the financial literacy and accounting information can also help less experienced investors in making good investment decision.

It will also serve as a reference material and future guideline for further research.

\subsection{DELIMITATION OF THE STUDY:}

Despite of loads of burden at the end of semester and shortage of time, due care was taken not to sacrifice the quality and in-depth of this study. This study as shown has attempted to identify the different investment behavior of investors in Karachi.

\subsection{DEFINITION OF THE TERMS:}

- Financial Literacy refers to the set of skills and knowledge that allows an individual to make informed and effective decisions through their understanding of finances.

- Information Asymmetry deals with the study of decisions in transactions where one party has more or better information than the other.

- Accounting Information is that, it covers information used to prepare financial statements which report the results and financial position of a business to the decision makers.

\section{Literature Review:}

(Iqbal Mahmood, 2011) in the research examine the role of various socioeconomic and demographic factors affecting the investment decision of investors. An investment model was developed that described the impact of past investment experiences of investors,variation in regulatory policies, asymmetric information, their marital status,gender, and reinvestment intentions of investors.they suggested that risk perception performs the key role in the investment decision process and that the variation in the government policies can impact the risk perception of an investor.

(Zakaria, 2008) in his research about investment in Pakistan evaluated the investment climate in Pakistan. Paper highlighted that high doing business cost, political instability, corruption, government bureaucracy, inconsistent government policies and poor law and order situation discourage the investors. There is a strong perception among investors that the pro-business policies to attract new investors are somehow weak and there is a need that government should invite the investment foreign exchange earning sector and other sectors simultaneously. (Shyan-Rong, 2010)An empirical study conducted by Shyan, Gow and Hui(2010) among Taiwanese investors to determine their past experiences and their outcomes when exposed to the economic signals. Empirical results found no difference by gender to investor propensity to take risk. However, higher and lower perceptions of risk were indicated by investors according to their personal investment experience. Investors with little experience in stocks and structured notes were found to have significantly heightened perception of risk. Furthermore the married subjects believed that they have adequate financial management knowledge and can make better investment decision.

(Kumar, 2011) examined the factors influencing investor behavior by conducting a survey. The findings suggested that earning per share (EPS), foreign direct investment (FDI), and GDP growth rate are positively correlated and have a significance impact on stock prices of companies listed in KSE (Karachi Stock Exchange). It also suggested that ordinary investor have lots of awareness about these variables when they invest in the stock market. They tried to make clear the investment percentage changes in Karachi Stock Exchange due to EPS, FDI and GDP growth rate during the year 2001 and 2008. 
(Baba Shiv) focused on the relation between emotions and the investment behavior by empirically tested the behavoiur of 34 people in California, in which those people were given the limited amount of money and were asked to make their investment decision after enhancing their different emotions. The result suggested that the emotions triggered by a given situation help the decision making process by narrowing down the option of reaction, either by discarding those that are dangerous or by endorsing those that are advantageous. Emotions serve an adoptive role in speeding up the decision making process. However, depending on the circumstances, moods andemotions can play a useful as well as disruptive role in decision making.

(2010)An exploratory study of factors influencing investment decisions of potential investor conducted by Philmore and Tracey in Barbados, West Indies (2010). The study used a questionnaire of a sample of business students in an undergraduate institutions. It was found that attitude, subjective norms, perceived behavior control, and risk propensity were significant predictors of investment intentions. It was also found that risk propensity did not moderate the relationship between the variables and the investment intentions. The findings showed that the education in business finance can help to influence the investment decision.

(Gender differences in investment behaviour, 2006)According to a research conducted on the "GENDER DIFFERENCES IN INVESTMENT BEHAVIOUR" at Iowa State University, gender differences in this area is not significant, but the willingness to take risk varied significantly between men and women. A majority of the women in the study preferred taking average or below-average risks, whereas men preferred taking aboveaverage or substantial investment risks. Furthermore, women are more likely to have experienced a change in their involvement in investing due to a change in marital status, the arrival of a child, or the death of a family member. Men are more likely to increase their involvement due to retirement or sudden financial gain. For women, divorce is an important factor in bringing about increased financial involvement; for men, on the other hand, divorce is the least likely event to change their investment involvement.

(Shyan-Rong, Influence of information search on risky investment preferences, 2011)Research conducted by Shun and Chyan in Taiwan related to influence of information search on risky investment preferences suggested that digital information search increases the individual interest in the risky investment because investors might reduce their uncertainty via greater understanding of companies' financial status. It stated that due to lack of understanding for various risky investments, investors desire advice from professional advisor. They especially desire face to face contact when choosing the complex investments.

(Robert A.N.) examined the factors influencing investor behavior by conducting a survey. Their findings suggested that classical wealth maximization criteria are necessary to investors, even though investors employ different criteria when choosing stocks for investment. They tried to make clear the price changes due to the six speculation optional primary variables (payout ratio, size of the firm, asset growth, leverage, dividend yield and earning volatility) in Karachi Stock Exchange during the year 1981 to 2000. Their assessment indicates that variables other than prime variables may be more powerful and applicable to give an explanation the share price deviation in Pakistan.

(Tie)A survey conducting by Lawrence Tai about UAE investors' equity decision making concluded that UAE investor consider foreign market movements when they make equity investing decision. Portfolio analysis appears to have little or no affect on investors' approach to stock valuation. Individual investors prefer to use EPS and ROI, while professional investors to use P/E ratio and EPS in their analysis.

(An empirical evidence of factors in equ Tun-Pin Chong, 2011)An empirical research related to equity selection process in Malaysia conducted by Tun-Pin and Ming-Ming Lai indicated neutral information appeared to be the most important factor the Malaysian investors, followed by accounting information, social relevance and advocates' recommendations in equity selection process. Neutral information was positively correlated in while accounting information was negatively correlated with expected return. The study concluded that investment decision of investors did not rely on single integrated factor.

(Suleyman Gokhan Gunay, 2011) in the research about Demographics and Financial Behaviour found that gender has interaction with five financial behavior factors, that are, overreaction, herding, cognitive bias, irrational thinking and overconfidence. Whereas, level of individual savings has interaction with four financial behavior factors, which are, overreaction, herding, cognitive bias and irrational thinking. So it was concluded that gender and saving level are effective demographic factors that interact with behavioral finance factor in investment decision.

(The Case For Financial Literacy In Developing Countries, 2009)According to a Case For Financial Literacy In Developing Countries, given by The World Bank, consumers who are more financially literate are more likely to understand the importance of saving and to take action in that respect. Other potential economic benefits include better investment decision and use of financial products to facilitate business transaction.

(Brain Lucey, 2005)Research on the influence of feelings on investors' decision making process and equity pricing conducted by Brain Lucey and Micheal Dowling stated that investors allow the mood to influence at the time of making investment decision. But if the investor allow an irrelevant mood state to influence their 
judgement. There was another manner in which investor allow their feelings to influence in their investment decision and it was shown that people invest in the equity of the company based on their likes or dislikes.

(Natalie Gallery)Assessing the financial literacy and investment choice decision, Natalie,Cameron and Chrisann in their research study found that deficiencies in financial literacy is one of the cause of inertia in financial decision making and findings from international and Australian studies show that financial illiteracy is wide spread. Many of the individuals are investors who have no experience or interest in financial investment, yet are faced to select investment option, such members make complex investment decision during their working lives that can have far-reaching financial implications on retirement benefits.

\section{METHODOLOGY:}

The study aims at applied research and designed at casual research which will be empirically tested. The approach that will be used for this study is based on primary data collection using a questionnaire. Sampling technique used is based on probability sampling. The sample size will consist of 60 Karachi's individual investors. These responses have to come from executives, managers, officers, housewives, workers, teachers, students, and entrepreneurs of Karachi, aging from 18 onwards, but the ethnicity of these people can be from any religion, cast or culture. For these reasons it is appropriate to use a quantitative research approach.

\subsection{RESEARCH HYPOTHESIS:}

1) $\mathbf{H}_{\mathbf{0}}$ : Financial literacy and risk taking are in positive correlation.

$\mathbf{H}_{\mathbf{A}}$ : Financial literacy and risk taking are not in positive correlation

2) $\mathbf{H}_{\mathbf{0}}$ : Experience and propensity to risk are not in a direct relationship.

$\mathbf{H}_{\mathbf{A}}$ : Experience and propensity to risk are in a direct relationship.

3) $\mathbf{H}_{\mathbf{0}}$ : Accounting information and risk aversion are in inverse relationship.

$\mathbf{H}_{\mathbf{A}}$ : Accounting information and risk aversion are not in inverse relationship.

4) $\mathbf{H}_{\mathbf{0}}$ : Analysis of financial statements is important to lower information asymmetry.

$\mathbf{H}_{\mathbf{A}}$ : Analysis of financial statements cannot lower information asymmetry.

5) $\mathbf{H}_{\mathbf{0}}$ : Age and preference investment in shares are in perfect positive relationship.

1.7 $\mathbf{H}_{\mathbf{A}}$ : Age and preference investment in shares are not in perfect positive relationship.

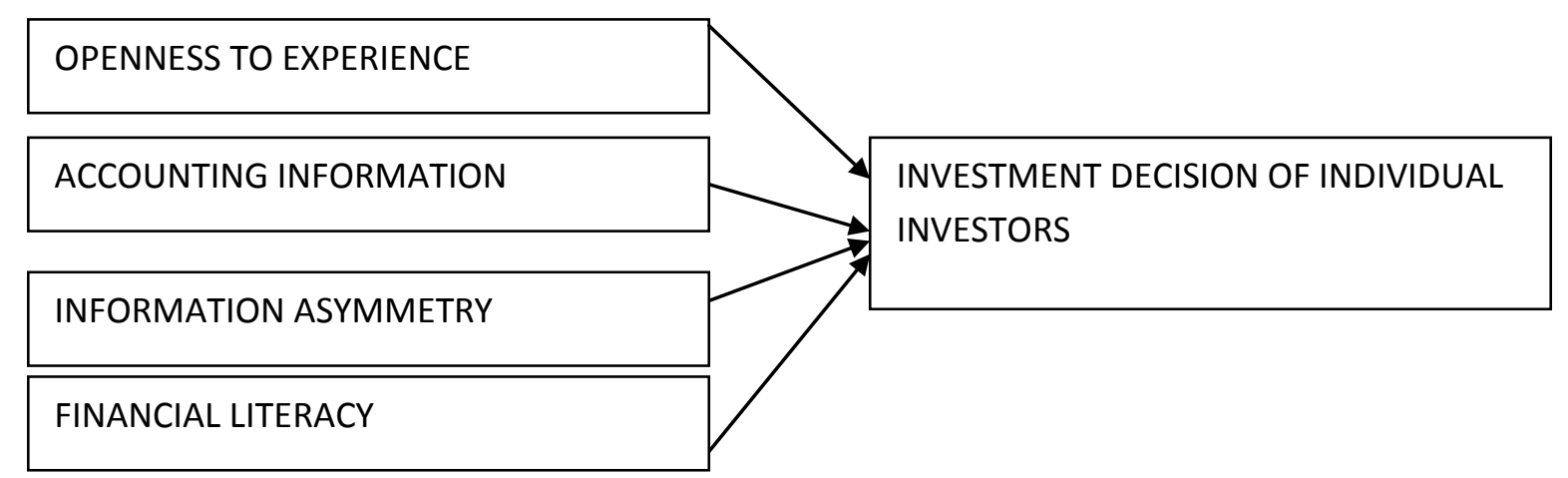

\subsection{RESEARCH DESIGN :}

Data collected for the research is primary and was gathered by distributing the questionnaire among the individual investors of Karachi. Individual investors include executives, managers, teachers, businessmen, white-collar workers, blue-collar workers, students and even housewives.

People surveyed age from 18 years onwards and irrespective of gender discrimination. Even the ethnicity of these people can be from any religion, cast or culture.

During its development, the questionnaire was tested to ensure that the only a valid sample's responses would be used in the survey. Most questions were check-list questions in which respondents were to choose only one option. Some questions were the likert scale type, to find out how important or unimportant investors consider analyzing financial statements for investment decision. 


\subsubsection{DATA SOURCE:}

Data gathered for the research is Primary and collected for the first time through questionnaire. However a little assistance was taken from the already existing journals and books on internet for determining the suitable variables, forming the questionnaire and interpreting the statistical results of the testing hypothesis.

\subsubsection{DATA TYPE:}

Data type is Quantitative and all questions in the questionnaire are close ended as the main objective of the study is to determine whether the relationship between variables exist or not? And if it exist, to what extent they are correlated and what is the statistical equation that links those variables?

\subsubsection{RESEARCH SAMPLE:}

Hundred questionnaires were distributed through mail, e-mail and surveyed through telephone, at different educational institutions. 14 people responded in telephonic survey, 26 through different educational institutes (including students, teachers and management), none of the questionnaire was received back from the e-mail, and 20 were received through mail. Therefore, out of 100, 60 questionnaires were found valid for the research study.

\subsubsection{SAMPLING TECHNIQUE:}

SIMPLE RANDOM PROBABILITY SAMPLING TECHNIQUE is used where every individual aging 18 years or above has an equal chance to be selected for survey.

\subsubsection{STATICAL TECHNIQUE USED:}

Software SPSS (statistical package for social science) is being used for finding the statistical relationship among variables. Association Statistical Inference technique is used that includes correlation and regression. Through correlation we came to know how much variables are linked together. And through regression we find out the perfect relationship equation of dependent and independent variables, that helped us to reach to predict the ultimate cause and effect relation between variables.

\subsubsection{RELIABILITY OF THE RESEARCH:}

The reliability of the research is satisfactory by the sufficient sample size and the heterogeneity of the population that is being chosen and keeping in view other environmental variables too.

\subsection{HYPOTHESIS 1:}

\section{Hypothesis Testing And Data Analysis:}

$\mathbf{H}_{\mathbf{0}}$ : Financial literacy and risk taking are in positive correlation.

$\mathbf{H}_{\mathbf{A}}$ : Financial literacy and risk taking are not in positive correlation

(Statistics of question \#5 and 8 of the research questionnaire are used to test this hypothesis) Correlations

\begin{tabular}{|c|c|c|c|}
\hline & & $\begin{array}{lr}\text { RISK } & \text { TAKING } \\
\text { OR } & \text { RISK } \\
\text { AVERSION } & \\
\end{array}$ & $\begin{array}{lrll}\text { FINANCIAL } & \text { LITERACY } & \text { HELPS } & \text { IN } \\
\text { INVESTMENT DECISION } & & \end{array}$ \\
\hline $\begin{array}{l}\text { RISK TAKING } \text { OR RISK } \\
\text { AVERSION } \\
\begin{array}{l} \\
\text { FINANCIAL }\end{array} \\
\text { HELPS IN } \\
\text { DECISION }\end{array}$ & $\begin{array}{l}\text { Pearson Correlation } \\
\text { Sig. (1-tailed) } \\
\mathrm{N} \\
\text { Pearson Correlation } \\
\text { Sig. (1-tailed) } \\
\mathrm{N}\end{array}$ & $\begin{array}{l}1 \\
60 \\
.135 \\
.151 \\
60 \\
\end{array}$ & $\begin{array}{l}.135 \\
.151 \\
60 \\
1 \\
60\end{array}$ \\
\hline
\end{tabular}

Coefficients $^{\mathrm{a}}$

\begin{tabular}{|c|c|c|c|c|c|c|}
\hline \multirow[t]{2}{*}{ Model } & & \multicolumn{2}{|c|}{ Unstandardized Coefficients } & \multirow{2}{*}{$\begin{array}{l}\text { Standardized } \\
\text { Coefficients } \\
\text { Beta }\end{array}$} & \multirow[t]{2}{*}{$\mathrm{t}$} & \multirow[t]{2}{*}{ Sig. } \\
\hline & & B & Std. Error & & & \\
\hline & (Constant) & 1.356 & .198 & & 6.856 & .000 \\
\hline 1 & $\begin{array}{l}\text { FINANCIAL LITERACY HELPS } \\
\text { IN INVESTMENT DECISION }\end{array}$ & .156 & .149 & .135 & 1.041 & .302 \\
\hline
\end{tabular}

a. Dependent Variable: RISK TAKING OR RISK AVERSION

Correlation 0.135 proves that financial literacy and risk taking have positive correlation and as significant value 0.151 is greater than 0.05 therefore we ACCEPT the NULL HYPOTHESIS that "financial literacy and investment in risky instruments are in positive correlation" and their regression equation is: 


$$
\mathrm{Y}=1.356+0.156 \mathrm{X}
$$

Where : $\mathrm{Y}$ (risk taking) and $\mathrm{X}($ financial literacy)

\subsection{HYPOTHESIS 2:}

$\mathbf{H}_{\mathbf{0}}$ : Experience and propensity to risk are not in a direct relationship.

$\mathbf{H}_{\mathrm{A}}$ : Experience and propensity to risk are in a direct relationship.

(Statistics of question \#4and 9 of the research questionnaire are used to test this hypothesis)

\begin{tabular}{|c|c|c|c|c|}
\hline & & & $\begin{array}{l}\text { MORE } \\
\text { EXPERIENCED } \\
\text {;HIGHER } \\
\text { PROPENSITY TO } \\
\text { RISK }\end{array}$ & $\begin{array}{l}\text { PREFERENCE } \\
\text { INVESTMENT IN } \\
\text { SHARES }\end{array}$ \\
\hline Spearman's rho & $\begin{array}{l}\text { MORE EXPERIENCED ; HIGHER } \\
\text { PROPENSITY TO RISK } \\
\text { PREFERENCE INVESTMENT IN } \\
\text { SHARES }\end{array}$ & $\begin{array}{l}\text { Correlation Coefficient } \\
\text { Sig. (1-tailed) } \\
\mathrm{N} \\
\text { Correlation Coefficient } \\
\text { Sig. (1-tailed) } \\
\mathrm{N}\end{array}$ & $\begin{array}{l}1.000 \\
60 \\
-.186 \\
.078 \\
60\end{array}$ & $\begin{array}{l}-.186 \\
.078 \\
60 \\
1.000 \\
. \\
60 \\
\end{array}$ \\
\hline
\end{tabular}

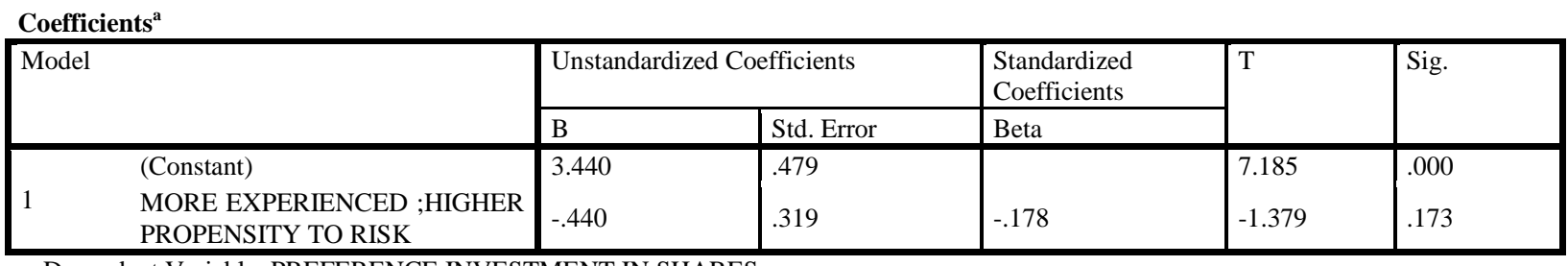

a. Dependent Variable: PREFERENCE INVESTMENT IN SHARES

Spearman's correlation was run to determine the relationship between experience and propensity to risk. There is a negative correlation between them which is statistically insignificant $(r=-0.186, p=0.078)$ that is we ACCEPT the NULL HYPOTHESIS that "experience and propensity to risk are not in a direct relationship. The regression equation is:

$$
\mathrm{Y}=3.44-0.44 \mathrm{X}
$$

Where, $Y=$ preference investment in shares (i.e risky investment) $\mathrm{X}=$ higher experience

\subsection{HYPOTHESIS 3:}

$\mathbf{H}_{\mathbf{0}}$ : Accounting information and risk aversion are in inverse relationship.

$\mathbf{H}_{\mathbf{A}}$ : Accounting information and risk aversion are not in inverse relationship.

\begin{tabular}{|c|c|c|c|}
\hline & & $\begin{array}{l}\text { ACCOUNTING } \\
\text { INFORMATION } \\
\text { ASSISTS IN } \\
\text { INVESTMENT } \\
\text { DECISION }\end{array}$ & RISK TAKING OR RISK AVERSION \\
\hline 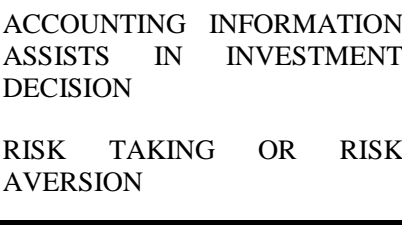 & $\begin{array}{l}\text { Pearson Correlation } \\
\text { Sig. (1-tailed) } \\
\mathrm{N} \\
\text { Pearson Correlation } \\
\text { Sig. (1-tailed) } \\
\mathrm{N}\end{array}$ & $\begin{array}{l}1 \\
60 \\
.271^{*} \\
.018 \\
60\end{array}$ & $\begin{array}{l}.271^{*} \\
.018 \\
60 \\
1 \\
60\end{array}$ \\
\hline
\end{tabular}

(Statistics of question \#5and 11 of the research questionnaire are used to test this hypothesis)

*. Correlation is significant at the 0.05 level (1-tailed). 


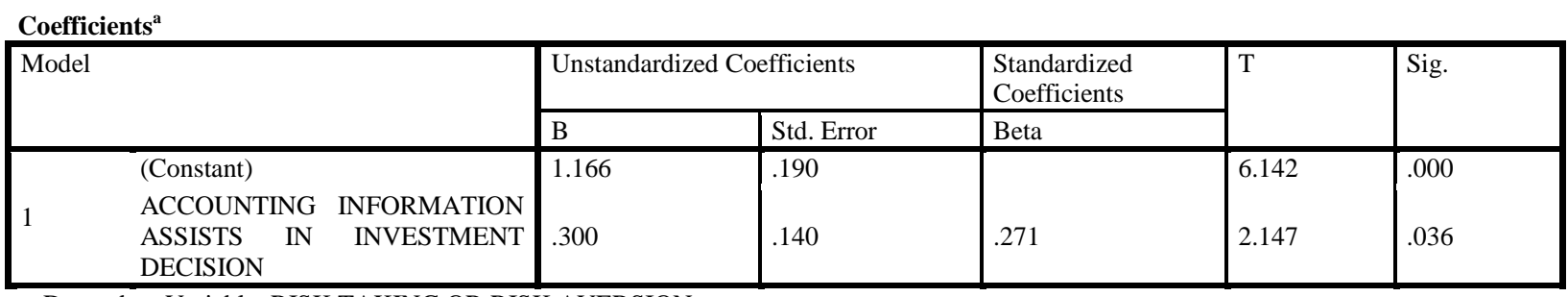

a. Dependent Variable: RISK TAKING OR RISK AVERSION

Pearson correlation was run to determine the relationship between accounting information and risk aversion. There is a positive correlation between them which is statistically significant $(r=0.271, p=0.018)$ that is we REJECT the NULL HYPOTHESIS that "Accounting information and risk aversion are in inverse relationship". The regression equation is:

$$
\mathrm{Y}=1.166+0.3 \mathrm{X}
$$

Where: $\mathrm{Y}=$ risk aversion, $\mathrm{X}=$ accounting information

\subsection{HYPOTHESIS 4:}

$\mathbf{H}_{\mathbf{0}}$ : Analysis of financial statements is important to lower information asymmetry.

$\mathbf{H}_{\mathbf{A}}$ : Analysis of financial statements cannot lower information asymmetry.

(Statistics of question \#7and 12 of the research questionnaire are used to test this hypothesis)

Correlations

\begin{tabular}{|c|c|c|c|}
\hline & & $\begin{array}{l}\text { IMPORTANCE OF } \\
\text { FINANCIAL } \\
\text { STATEMENT IN } \\
\text { INVESTMENT } \\
\text { DECISION }\end{array}$ & $\begin{array}{l}\text { INFORMATION ASYMMETRY } \\
\text { INVESTMENT SELECTION }\end{array}$ \\
\hline $\begin{array}{ll}\text { IMPORTANCE OF FINANCIAL } \\
\text { STATEMENT IN INVESTMENT } \\
\text { DECISION } & \\
\text { INFORMATION } & \text { ASYMMETRY } \\
\text { AND } & \text { INVESTMENT } \\
\text { SELECTION } & \end{array}$ & $\begin{array}{l}\text { Pearson Correlation } \\
\text { Sig. (1-tailed) } \\
\mathrm{N} \\
\text { Pearson Correlation } \\
\text { Sig. (1-tailed) } \\
\text { N }\end{array}$ & \begin{tabular}{|l|}
1 \\
60 \\
-.115 \\
.192 \\
60 \\
\end{tabular} & $\begin{array}{l}-.115 \\
.192 \\
60 \\
1 \\
60 \\
6\end{array}$ \\
\hline
\end{tabular}

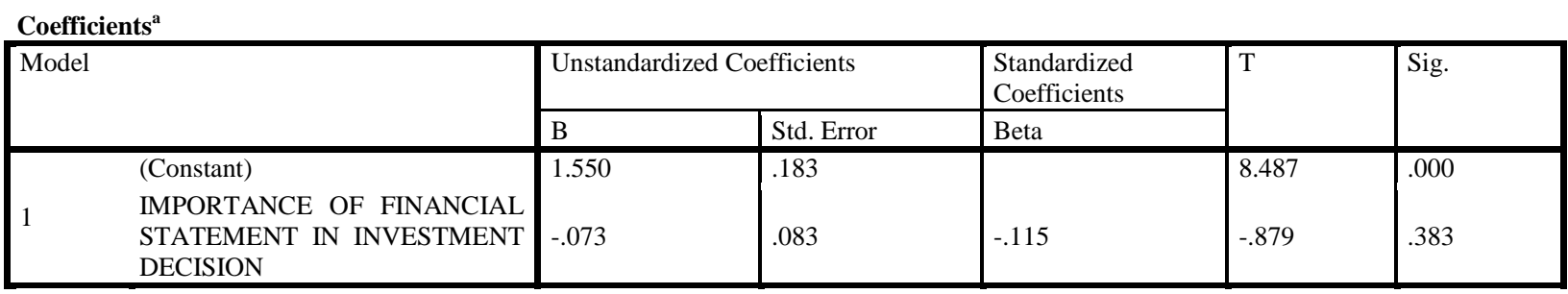

a. Dependent Variable: INFORMATION ASYMMETRY AND INVESTMENT SELECTION

Null hypothesis intends that higher the analysis of financial statements $(\mathrm{X})$, lower the information asymmetry(Y) and better will be the investment decision. Pearson correlation proves that there is a negative correlation between them that is statistically insignificant ( $\mathrm{r}=$ $0.115, \mathrm{p}=0.192)$, therefore we ACCEPT the NULL HYPOTHESIS that" analysis of financial statements is important to lower information asymmetry. The regression equation is:

$$
\mathrm{Y}=1.550-0.073 \mathrm{X}
$$

\subsection{HYPOTHESIS 5:}

$\mathbf{H}_{\mathbf{0}}$ : Age and preference investment in shares are in perfect positive relationship.

$\mathbf{H}_{\mathbf{A}}$ : Age and preference investment in shares are not in perfect positive relationship.

\begin{tabular}{|c|c|c|c|c|}
\hline Correlations & & & & \\
\hline & & & AGE & $\begin{array}{l}\text { PREFERENCE } \\
\text { INVESTMENT } \\
\text { SHARES }\end{array}$ \\
\hline Spearman's rho & AGE & $\begin{array}{l}\text { Correlation Coefficient } \\
\text { Sig. (1-tailed) }\end{array}$ & 1.000 & $\begin{array}{l}.219^{*} \\
.047\end{array}$ \\
\hline
\end{tabular}

(Statistics of question \# 1 and 4 of the research questionnaire are used to test this hypothesis) 


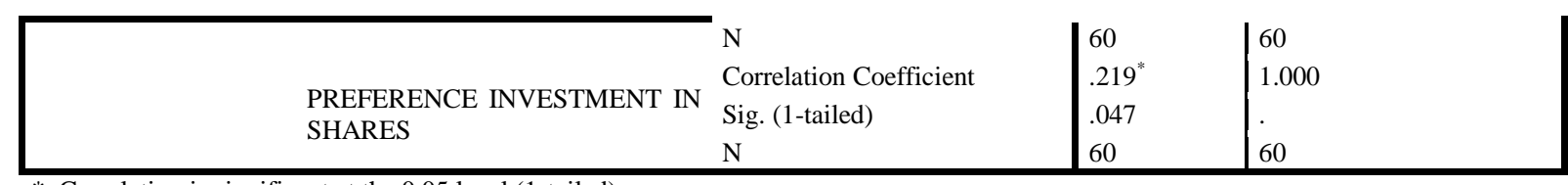

*. Correlation is significant at the 0.05 level (1-tailed).

Coefficients $^{\mathrm{a}}$

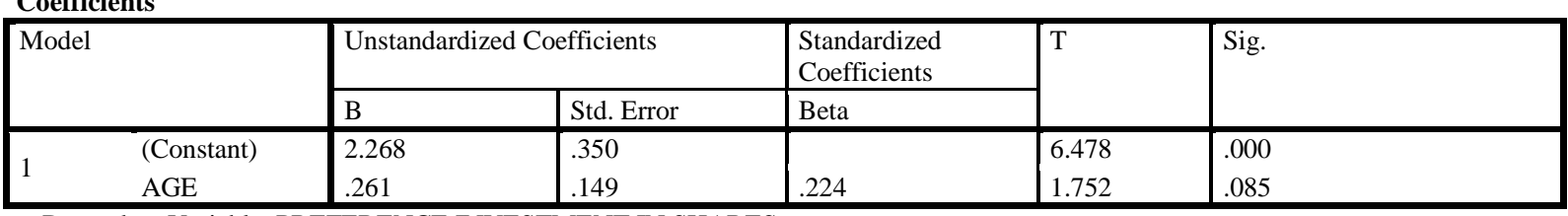

a. Dependent Variable: PREFERENCE INVESTMENT IN SHARES

Spearman correlation was run to determine the relationship between accounting age and preference investment in shares. Though there is a positive correlation between them but not perfect positive which is statistically significant $(\mathrm{r}=0.219, \mathrm{p}=0.047)$ that is we REJECT the NULL HYPOTHESIS that "Age and preference investment in shares are in perfect positive relationship". The regression equation is:

$$
Y=2.268+0.261 X
$$

Where: $Y=$ preference investment in shares, $\mathrm{X}=$ age

\section{Conclusion:}

In this study factors influencing the individual investor's behavior were examined. Quantitative research was conducted to determine the relationship between desired explanatory and response variables. There were five independent variables including; financial literacy, high experience, use of accounting information, importance of analyzing financial statements and age that might affect the investment decision of any individual. Five different dependent variables were chosen from the questionnaire to reach to any conclusion they were; risk taking, preference investment in shares (risky investment), risk aversion, information asymmetry and shares investment.

The obtained result for hypothesis 1 , (that says that financial literacy and risk taking are in positive correlation), proves that as the financial literacy of a person increases his risk taking capability increases, as analyzing financial statements clues the investors which company can give better capital gain. However hypothesis related to experience and propensity to risk says that they are in inverse relation that is as investors' experience will increase he will invest in less risky instruments; they may be fixed deposits or high pay dividend stocks.

Study also proves statistically that accounting information and risk aversion are in direct relationship, that is along with experience as person's accounting information increases he prefers to invest in less risky investments, it may be investor accepts to get lower but is not ready to suffer huge loss. Usually old age people or the retired people are found with this concept.

Survey statistics show high response who say that information asymmetry leads to adverse selection of investments. To overcome this problem hypothesis was tested whose results say that information asymmetry can be lower by analyzing more and more financial statements. The more and detail investor will study the financial statements of the desired company better will be his investment decision.

Analysis of relation between age and preference investment in shares shows that both are in positive relation but not perfect positive. As the age of an investor increases he may prefers to invest in shares but it's not necessary that he invested in shares with the intension of getting the capital gain, as stated above that old citizens are risk averse so they can chose stocks as their preference investments because of high dividend payout.

In the end it was concluded that financial literacy and accounting information helps investors in lowering information asymmetry and allows investors to invest in risky instruments. But as age and experience increase investors preference changes to less risky investments, it does not mean that investor does not prefer to invest in shares, he will but with the intension of getting dividend return rather than capital gain.

\section{Acknowledgement}

I thank Allah for guiding me through the phases of compiling this research study and helping me in all the difficulties.

It could not have been made possible without the immense help and cooperation of my family members, course instructor and my classmates. Without their support and the amount of time that they gave me, this report would not have existed. 


\section{Bibliography}

[1]. (2010). Barbodas, West Indies: Central board of Barbodas.

[2]. An empirical evidence of factors in equ Tun-Pin Chong, M.-M. L. (2011). An empirical evidence of factors in equity selection process in Malaysia. An empirical evidence of factors in equity selection process in Malaysia by African Journal of Business Management, 6221-6232.

[3]. Baba Shiv, G. L. Investment behaviour and the negative side of emotion. Americal psychological society , 16, 435439.

[4]. Brain Lucey, M. D. (2005). The Role Of Feelings In Investor Decision Making. Journal Of Economic Surveys , 19.

[5]. (2006). Gender differences in investment behaviour. Milestone.

[6]. Iqbal Mahmood, H. A. (2011). Behavioural implications of investors for investments in the stock market. European journal of social science, 20.

[7]. Kumar, M. A. (2011). Factors influencing the individual investor and stock price variation. Australian journal of basic and applied science, 3040-3043.

[8]. Natalie Gallery, C. N. Framework for Assessing Financial Literacy and Superannuation Investment Choice Decisions . Australasian Accounting Business and Finance Journal , 5 (2).

[9]. Robert A.N., R. Factors influencing the individual investor behaviour. Financial analyst journal, 50 (04), 63-68.

[10]. Shyan-Rong, C.-L. H.-L. (2011). Influence of information search on risky investment preferences. International conference on information and financial engineering. Singapore: IPEDR.

[11]. Shyan-Rong, C.-L. H.-L. (2010). Investor attitudes and behaviour towards inherent risk and potential return in financial products. International research journal of finance and economics (44), 16-29.

[12]. Suleyman Gokhan Gunay, E. D. (2011). Interaction between Demographic and Financial Behavior Factors in Terms of Investment Decision Making. International Research Journal of Finance and Economics (66), 1450-2887.

[13]. The Case For Financial Literacy In Developing Countries (2009).

[14]. Tie, L. (n.d.). Making Equity Investing Decisions: A Survey of UAE Investors. Middle east journal of Business .

[15]. Zakaria, M. (2008). Investment in Pakistan. MPRA paper. 